3 Design defines the effects of nanoceria at a low dose on soil microbiota and the potentiation of 4 impacts by canola plant

5 Mohamed Hamidat ${ }^{1,2}$, Mohamed Barakat ${ }^{1,2}$, Philippe Ortet $^{1,2}$, Corinne Chanéac ${ }^{2,3}$, Jérome Rose ${ }^{2,4}$, 6 Jean-Yves Bottero ${ }^{2,4}$, Thierry Heulin ${ }^{1,2}$, Wafa Achouak ${ }^{1,2}$, and Catherine Santaella*1,2

7

8 1. Aix-Marseille Université, CEA, CNRS, Biosciences and biotechnology Institute of Aix-Marseille 9 (BIAM, DRF), UMR 7265, Laboratory of Microbial Ecology of the Rhizosphere and Extreme 10 Environments (LEMIRE), CEA Cadarache, St-Paul-lez-Durance, France

11 2. GDRi iCEINT, international Consortium for the Environmental Implication of Nanotechnology, 12 CNRS-Duke University, F-13545 Aix-en-Provence, France

13 3. Chimie de la Matière Condensée, UMR7574, Collège de France, Université de Jussieu, Paris, F1475231 , France

4. CNRS, Aix-Marseille Université, IRD, CEREGE UM34, F-13545 Aix en Provence, France

SUMMARY: 19 pages, 5 methods, 5 figures and 6 tables

20 Figure S1: Catalase mimetic activity of nanoceria.

21 Figure S2: Impact of nanoceria on the $\alpha$-diversity of bulk soil, rhizosphere and root microbiota.

22 Figure S3: Jackknifed beta diversity presented as PCoA plots of unweighted UniFrac (a), weighted 23 UniFrac (b) and Bray-Curtis (c) distances. 
24 Figure S4: Percent composition of each group by phylum in root, rhizosphere and bulk soil 25 compartments for plants grown in soil spiked with nanoceria (pristine $\mathrm{CeO}_{2}-\mathrm{R}, \mathrm{CeO}_{2}-\mathrm{U}$ and citrate coated $\mathrm{CeO}_{2}$ ) at $1 \mathrm{mg} \cdot \mathrm{kg}^{-1}$ or with no nanoceria (controls, Ctrl).

27 Figure S5: Impact of nanoceria on plant growth. Dry mass ( \pm Standard Error, SE) of plant shoots 28 (white circles) and roots (dark circles) for plants grown in soil spiked with $1 \mathrm{mg}^{-\mathrm{kg}^{-1}}$ of nanoceria and 29 controls. ANOVA analysis showed no significant effect of nanoceria $(\mathrm{P} \geq 0.05)$.

30 Table S1: Physico-chemical characteristics of nanomaterials (NM) in water.

31 Table S2: Characteristics of soil used in the study.

32 Table S3: Extractable soil DNA and bacterial abundance in the different treatments.

33 Table S4: Significant differences between treatments at the phylum taxonomic level in the root 34 compartment.

35 Table S5: Significant differences in relative abundances between treatments at the phylum taxonomic 36 level in the root compartment.

37 Table S6: Analysis of differences in relative abundance at the family, genus and species levels.

\section{Plant growth}

Seeds of Brassica napus (colza hybrid; www.semencesdefrance.com) were sterilized 15 min under

41 stirring in $60 \mathrm{~mL}$ of sterilized UPW with $2.5 \%$ sodium dichloroisocyanurate and $60 \mu \mathrm{L}$ Tween ${ }^{\mathrm{TM}} 20$; seeds were subsequently washed four times, $15 \mathrm{~min}$ each, in $60 \mathrm{~mL}$ UPW. The seeds were rinsed with alcohol and dried under a laminar flow safety hood. Seeds were planted just below the surface of the

44 soil. Soil humidity was set to $20 \%$. A layer of sand was added to the top to isolate the aboveground plant tissue from the soil, and the pot was protected from light to prevent the formation of algae. For each condition, triplicate pots with plants or without plants (i.e. unplanted or bulk soil) were incubated in a climate-controlled growth chamber (Phytotech, IBEB, CEA Cadarache, France) equipped for automatic control of light ( $250 \mu \mathrm{mol}$ photon. $\mathrm{m}^{-2} \cdot \mathrm{s}^{-1}$ intensity), temperature $\left(19-22^{\circ} \mathrm{C}\right.$ thermoperiod $)$, air moisture (70-80\%), evapotranspiration, irrigation and $\mathrm{CO}_{2}$ concentration $(380 \mathrm{ppm})$, with a $8 \mathrm{~h}: 16 \mathrm{~h}$

50 day:night period. Dripping deionized water was automatically dispensed once a day to set the soil 51 moisture near $20 \%$ humidity. 
Enzymatic activities

54 Catalase activity (EC 1.11.1.6) was measured according to the method of Li et al. (2010), ${ }^{1}$ with minor 55 modifications. Catalase was analyzed based on the rate of recovery of $\mathrm{H}_{2} \mathrm{O}_{2}$ and was expressed as 0.1 56 mol. $\mathrm{L}^{-1} \mathrm{KMnO}_{4} \mathrm{~mL} \cdot \mathrm{g}^{-1}$ dry soil mass. Soil sub-samples $(0.5 \mathrm{~g})$ were added to $4 \mathrm{~mL}$ distilled water and $57 \quad 100 \mu \mathrm{L}$ of $3 \% \mathrm{H}_{2} \mathrm{O}_{2}$ solution. The mixture was shaken for $20 \mathrm{~min}(150 \mathrm{rpm})$ and the reaction was stopped by adding $0.5 \mathrm{~mL}$ of $1.5 \mathrm{~mol} . \mathrm{L}^{-1}$ sulfuric acid. The mixture was filtered through a $0.45-\mu \mathrm{m}$ membrane filter and titrated using 0.1 mol. $\mathrm{L}^{-1} \mathrm{KMnO}_{4}$. Catalase activity is expressed as $\mu \mathrm{mol}$ $60 \mathrm{KMnO}_{4} \cdot \mathrm{g}^{-1}$ dry soil. $\mathrm{min}^{-1}$.

61

$\beta$-glucosidase activity (EC 3.2.1.21) was measured according to the method of Turner et al., ${ }^{2}$ with minor modifications. Fresh soil sub-samples $(500 \mathrm{mg})$ were incubated for $1 \mathrm{~h}$ at $37^{\circ} \mathrm{C}$ with $0.5 \mathrm{~mL}$ of $0.05 \mathrm{M}$ modified universal buffer (pH 6.0) and $100 \mu \mathrm{L}$ of $25 \mathrm{mM}$ 4-nitrophenyl $\beta$-D-glucopyranoside. The reaction was terminated by adding $100 \mu \mathrm{L}$ of $0.5 \mathrm{M} \mathrm{CaCl}_{2}$ and $500 \mu \mathrm{L}$ of $0.2 \mathrm{M}$ tris66 hydroxymethyl(aminomethane), $\mathrm{pH} 12$. The mixture was centrifuged for $10 \mathrm{~min}$ at 5,000 $\mathrm{g}$ and the 67 absorbance was measured at $410 \mathrm{~nm}$. $\beta$-glucosidase activity is expressed as $\mu$ mol of nitrophenyl 68 released $\mathrm{g}^{-1}$ dry soil.h $\mathrm{h}^{-1}$.

Phenoloxidase (EC 1.14.18.1) and peroxidase (EC 1.11.1.7) activities were measured 71 spectrophotometrically using 1-3, 4-dihydroxyphenylalanine (DOPA) as the substrate, according to 72 Saiya-Cork et al., ${ }^{3}$ with minor modifications. Fresh soil sub-samples $(0.5 \mathrm{~g})$ were suspended in 1.25 $\mathrm{mL}$ of $50 \mathrm{mM}$ acetate buffer (pH 5.0) and homogenized for $1 \mathrm{~min}$. For phenol oxidase, $50 \mu \mathrm{L}$ of 25 mM DOPA was added to $200 \mu \mathrm{L}$ of sample suspension dispensed into microplate wells. Peroxidase assays received $50 \mu \mathrm{L}$ of $25 \mathrm{mM}$ DOPA plus $10 \mu \mathrm{L}$ of $0.3 \% \mathrm{H}_{2} \mathrm{O}_{2}$. The microplates were incubated in

76 the dark at $20^{\circ} \mathrm{C}$ for up to $18 \mathrm{~h}$. Activity was quantified by measuring absorbance at $450 \mathrm{~nm}$ using a 77 microplate spectrophotometer (Infinite ${ }^{\circledR M} 1000$, Tecan) and expressed in $\mu$ mol. $\mathrm{h}^{-1} \cdot \mathrm{g}^{-1}$. 

$h^{-1}$.

Protease activity was analyzed as described by Ge et al., ${ }^{4}$ according to a standard procedure using casein as a substrate. Fresh soil sub-samples $(200 \mathrm{mg})$ were incubated for 2 hours at $50^{\circ} \mathrm{C}$ with $500 \mu \mathrm{L}$ $0.2 \mathrm{M}$ Tris buffer $\mathrm{pH} 8$ and $500 \mu \mathrm{L}$ of $20 \mathrm{~g} . \mathrm{L}^{-1}$ casein solution under agitation. The reaction was subsequently stopped by adding $500 \mu \mathrm{L}$ of $30 \%$ trichloroacetic acid. The reaction mixture was centrifuged at $5,000 \mathrm{~g}$ for $10 \mathrm{~min} .100 \mu \mathrm{L}$ of clear supernatant was mixed with $200 \mu \mathrm{L}$ of $500 \mathrm{mM}$ $\mathrm{Na}_{2} \mathrm{CO}_{3}$ and $100 \mu \mathrm{L}$ of 3 -fold diluted Folin and Ciocalteu's phenol reagent. The mixture was incubated for $1 \mathrm{~h}$ at room temperature and the absorbance of this solution was measured at $700 \mathrm{~nm}$ (Infinite ${ }^{\circledR M 1000, ~ T e c a n) . ~ T h e ~ r e l e a s e d ~ L-t y r o s i n e ~ c o n c e n t r a t i o n ~ w a s ~ d e t e r m i n e d ~ b y ~ m a k i n g ~ a ~}$ comparison with a calibration curve using L-tyrosine as a standard. Protease activity is expressed as $\mu \mathrm{g}$ of L-tyrosine released.g $\mathrm{g}^{-1}$ dry soil. $\mathrm{h}^{-1}$.

Alkaline phosphatase (EC 3.1.3.1) was determined according to Anupama et al. ${ }^{5} 500 \mathrm{mg}$ of soil were suspended in $500 \mu \mathrm{L}$ with Tris- $\mathrm{HCl}$ buffer (pH 8.0) and $100 \mu \mathrm{L}$ of $10 \mathrm{mM}$ para-nitrophenyl phosphate (p-NPP) (Sigma-Aldrich) were added as substrate. The mixture was thoroughly mixed and incubated at $37^{\circ} \mathrm{C}$ for $1 \mathrm{~h}$. After incubation, $500 \mu \mathrm{L}$ of $1 \mathrm{M} \mathrm{NaOH}$ was added to stop the reaction. The sample was then centrifuged at 5,000 g for $10 \mathrm{~min}$ and the supernatant was read at $418 \mathrm{~nm}$ using a microplate spectrophotometer (Infinite ${ }^{\circledR} M 1000$, Tecan). Alkaline phosphatase activity is expressed as $\mu \mathrm{mol}$ of pNP released.g $\mathrm{g}^{-1}$ dry soil. $\mathrm{h}^{-1}$.

Acid phosphatase (EC 3.1.3.2) was analyzed according to Bargaz et al. ${ }^{6}$ Soil from each treatment (200 mg) was suspended in $500 \mu \mathrm{L}$ of $0.2 \mathrm{M}$ sodium acetate buffer $\mathrm{pH} 5.6$ and $100 \mu \mathrm{L}$ of $10 \mathrm{mM}$ 4nitrophenylphosphate. After 30 min of incubation at $30^{\circ} \mathrm{C}, 125 \mu \mathrm{L}$ of $0.5 \mathrm{M} \mathrm{CaCl}_{2}$ and $500 \mu \mathrm{L}$ of $1 \mathrm{M}$ $\mathrm{NaOH}$ were added to stop the reaction. The samples were centrifuged for $10 \mathrm{~min}$ at 5,000 $\mathrm{g}$ and the supernatant absorbance was measured at $418 \mathrm{~nm}$ using a microplate spectrophotometer (Infinite ${ }^{\circledR M 1000, ~ T e c a n) . ~ A c i d ~ p h o s p h a t a s e ~ a c t i v i t y ~ i s ~ e x p r e s s e d ~ a s ~} \mu \mathrm{mol}$ of $\mathrm{p}-\mathrm{NP}$ released. $\mathrm{g}^{-1}$ dry soil. 
Real-time PCR amplification was performed with the LightCycler ${ }^{\circledR} 480$ Real-Time PCR System

108 (Roche) using Syber Green I Master, which contains FastStart Taq DNA Polymerase and the DNA double-strand-specific SYBR Green I dye for product detection and characterization. Amplification

110 was performed in the variable V3 region using primers P3 and S10, which recognize conserved

111 regions of the rrs gene. ${ }^{7}$ Each well contained $10 \mu \mathrm{L}$ Syber Green I Master Mix X2, $1 \mu \mathrm{M}$ of each rrs

112 gene primer, $1 \mu \mathrm{L}$ of $50 \mathrm{x}$ diluted DNA template and $7 \mu \mathrm{L}$ UPW. The LightCycler experimental run

113 protocol included a denaturation step $\left(95^{\circ} \mathrm{C}\right.$ for $\left.10 \mathrm{~min}\right), 45$ cycles of amplification and quantification

$114\left(95^{\circ} \mathrm{C}\right.$ for $10 \mathrm{~s}, 53^{\circ} \mathrm{C}$ for $30 \mathrm{~s}, 72^{\circ} \mathrm{C}$ for $\left.20 \mathrm{~s}\right)$, and a melting curve program $\left(95^{\circ} \mathrm{C}\right.$ with a heating rate

115 of $1.1{ }^{\circ} \mathrm{C}$ per second and a continuous fluorescence measurement). All quantitative PCR reactions were

116 performed in duplicate. PCR efficiency was estimated to 1.83 by means of a standard curve on a series

117 of samples with controlled relative amounts of targeted template.

\section{Sequencing}

120 Barcoded amplicon sequencing to amplify rss gene regions V1-V3 was performed as described in the 121 Materials and Methods. A single-step 30 cycle PCR using HotStarTaq Plus Master Mix Kit (Qiagen; 122 Valencia, CA) was performed with the following conditions: $94^{\circ} \mathrm{C}$ for 3 minutes, followed by 28 123 cycles of $94^{\circ} \mathrm{C}$ for 30 seconds; $53^{\circ} \mathrm{C}$ for $40 \mathrm{~s}$ and $72^{\circ} \mathrm{C}$ for 1 minute; and a final elongation step at $12472^{\circ} \mathrm{C}$ for 5 minutes. A secondary PCR was performed for FLX Amplicon Sequencing under the same 125 conditions, by using special fusion primers designed with different tag sequences. ${ }^{8}$ After secondary 126 PCR, all amplicon products from different samples were mixed in equal concentrations and purified 127 using Agencourt Ampure beads (Agencourt Bioscience Corporation; MA, USA). Samples were 128 sequenced utilizing Roche 454 FLX Titanium instruments and reagents, following the manufacturer's 129 guidelines.

\section{Post-run analysis}

132 Sequence data were processed using a proprietary analysis pipeline (www.mrdnalab.com, MR DNA; 133 Shallowater, TX). Sequences were trimmed of barcodes and primers, and then short sequences 
134 (<200bp), sequences with ambiguous base calls, and sequences with homopolymer runs exceeding 6

135 bp were removed. Sequences were de-noised and chimeras were removed. ${ }^{8}$ Analysis of high136 throughput community sequencing data was performed with QIIME version 1.8. ${ }^{9}$ Operational

137 Taxonomic Units (OTUs) were then defined by clustering at 3\% divergence (97\% similarity) followed

138 by removal of singleton sequences. Final OTUs were taxonomically classified using RDP and

139 compiled into each taxonomic level into both "counts" and "percentage" files. OTU tables were

140 rarefied at a single sequencing depth to control for differences in sequencing depth. Alpha diversity

141 was determined using the observed number of OTUs, qualitative Chao1 index, Faith's Phylogenetic

142 Diversity (PD) and quantitative Shannon index. The observed number of OTUs is presented as

143 rarefaction curves to estimate how far the data are from observing all of the diversity in a sample; this

144 also enables comparing alpha diversity between samples. The Chao1, Shannon and PD indices are

145 represented as box plots based on distances between sample groupings after rarefaction. Significance

146 between treatments was determined by multiple two-sample t-tests and nonparametric P-values

147 calculated using 999 Monte Carlo permutations. Beta diversity was determined using unweighted and

148 weighted UniFrac ${ }^{10}$ and Bray-Curtis distances; these results were presented as principal coordinate

149 (PCoA) plots. The OTUs were considered at taxonomic levels from phylum to genus, and differences

150 in the relative abundance or UNIFRAC distance at different taxonomic levels were determined using

151 PERMANOVA (adonis, http://CRAN.R-project.org/package=vegan). A total of 459,709 valid reads

152 and 51,185 OTUs were obtained from the 36 samples through 454 pyrosequencing analysis. These

153 OTUs were assigned to 29 different phyla. Each of the 36 communities contained between 3,285 and

15435,089 reads, with OTUs ranging from 718 to 8,430 reads. The rarefaction curves (consisting of

155 observed OTUs and the Chaol estimator) tended to approach the saturation plateau for roots, but not

156 for rhizosphere and bulk soil samples (Fig. 1a). Good's coverage estimations revealed that 86-95\% of

157 the species were obtained in root samples, whereas $82-88 \%$ of the species were determined in soil 158 samples.

159 
a)

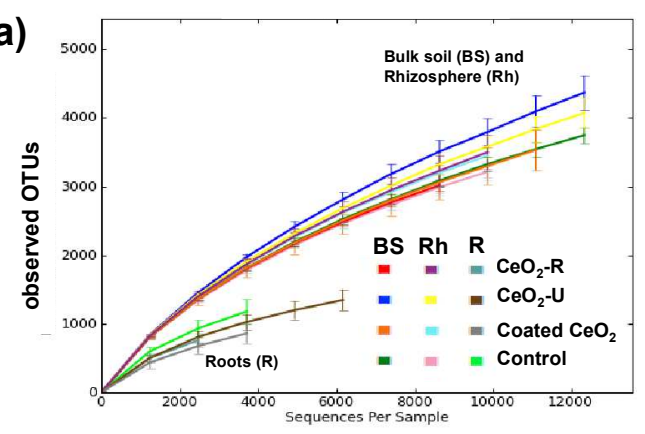

c)

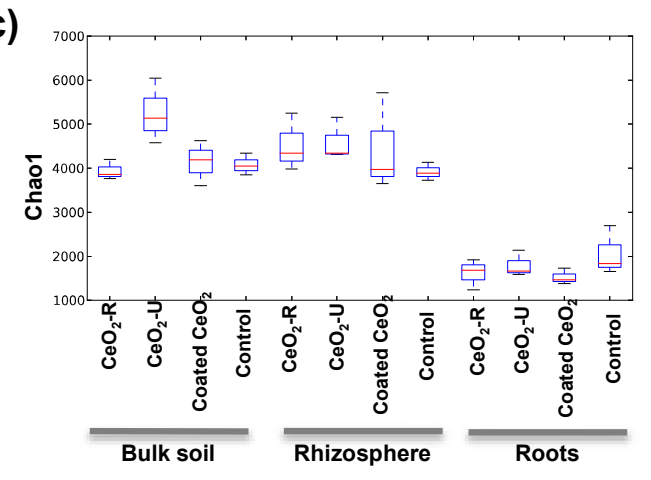

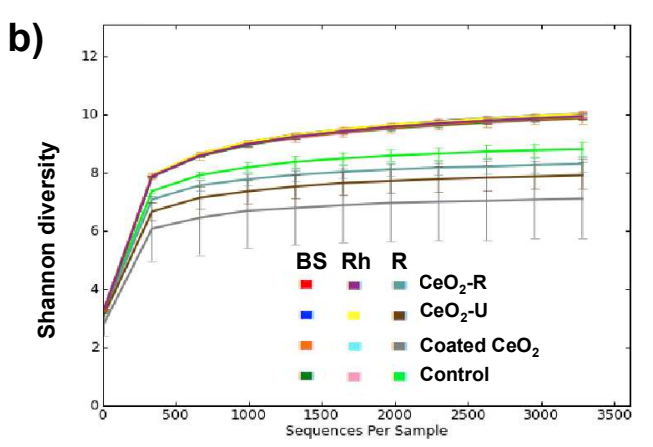

d)

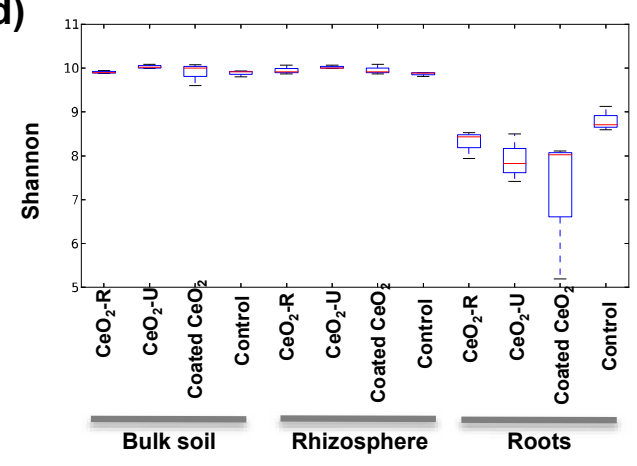

e)

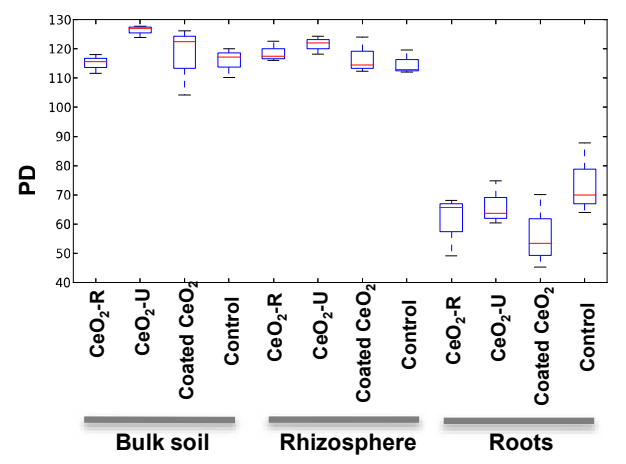

160

161 Figure S1: Impact of nanoceria on the $\alpha$-diversity of bulk soil, rhizosphere and root microbiota.

162 Rarefaction curves of observed OTUs (a) and Shannon diversity indices (b). Distance box plots of

163 Chaol (c), Shannon index (d) and rarefied PD (c)

164

165

166

167

168 


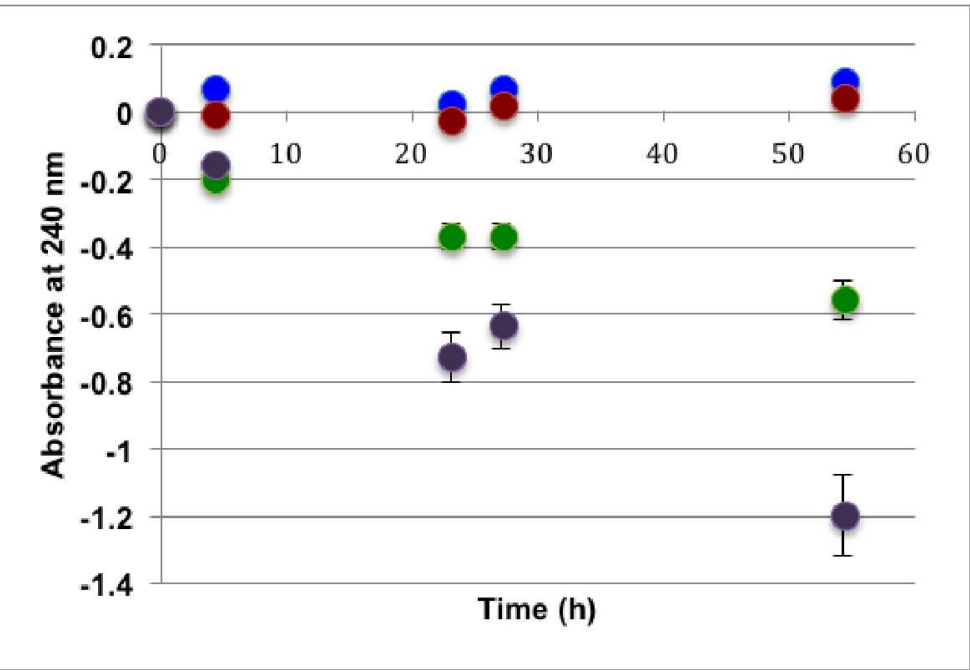

179

180

181 Figure S2: Catalase mimetic activity of nanoceria. Decrease in the absorbance at $240 \mathrm{~nm}$ for

182 incubations of $\mathrm{H}_{2} \mathrm{O}_{2}(3 \%, 10 \mu \mathrm{L})$ and nanoceria $\left(10\right.$ g. $\left.\mathrm{L}^{-1}\right), \mathrm{CeO}_{2}-\mathrm{R}$ (purple), coated $\mathrm{CeO}_{2}$ (green),

$183 \quad \mathrm{CeO}_{2}-\mathrm{U}$ (red) and control (blue).

184

185 


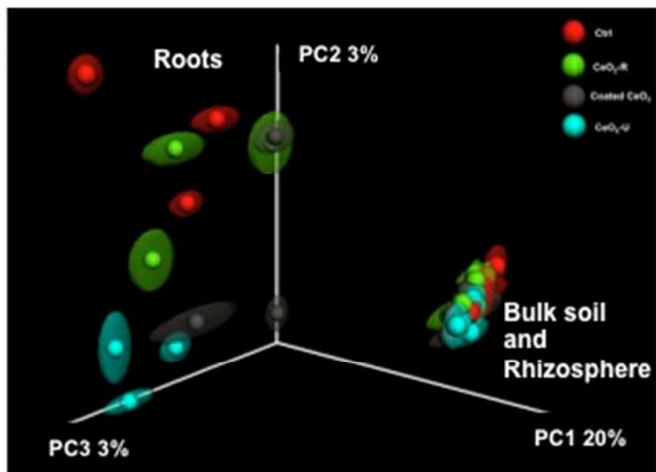

b)
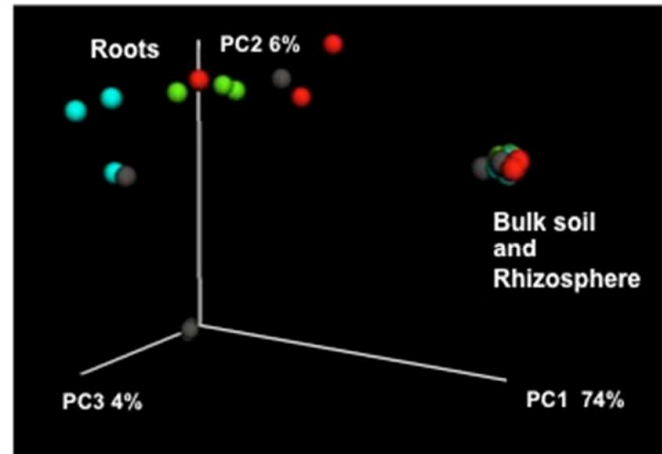

c)

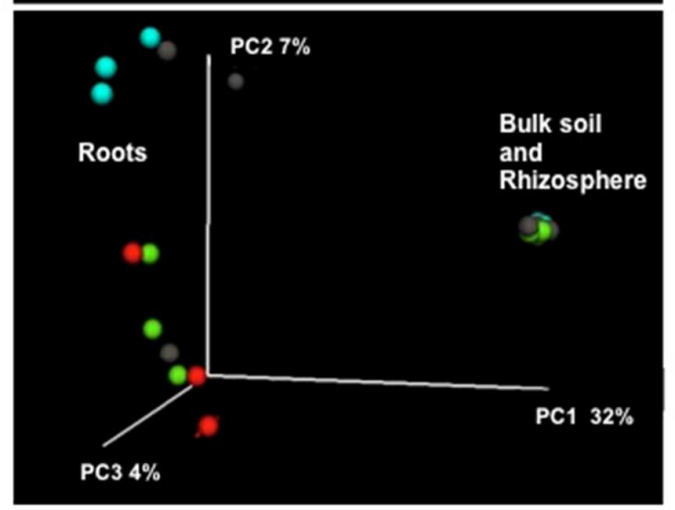

204

205 Figure S3: 3D jackknifed $\beta$-diversity presented as PCoA plots depicting the clusters of bacterial 206 communities within the different compartments (left: roots; right: rhizosphere and bulk soil) for the 207 nanoceria treatments $\mathrm{CeO}_{2}-\mathrm{R}$ (green), $\mathrm{CeO}_{2}-\mathrm{U}$ (blue), coated $\mathrm{CeO}_{2}$ (grey) and controls (red). 208 Unweighted UniFrac (a), weighted UniFrac (b), and Bray Curtis (c) distance metrics are shown. The 209 positions of the points are the average for 10 jackknife replicates. Ellipses show the confidence based 210 on these randomizations. Statistical analyses (PERMANOVA) of jackknifed PCoA of unweighted and 211 weighted UniFrac, as well as Bray-Curtis distances, revealed clustering of microbial communities 212 based on the soil compartment factor (Fig. S2a, $\mathrm{P}=0.0001$; Fig. S2b, $\mathrm{P}=0.0001$; Fig. S2c, $\mathrm{P}=0.001$, 213 PERMANOVA) but not on nanoceria treatment $(\mathrm{P}>0.05)$. 


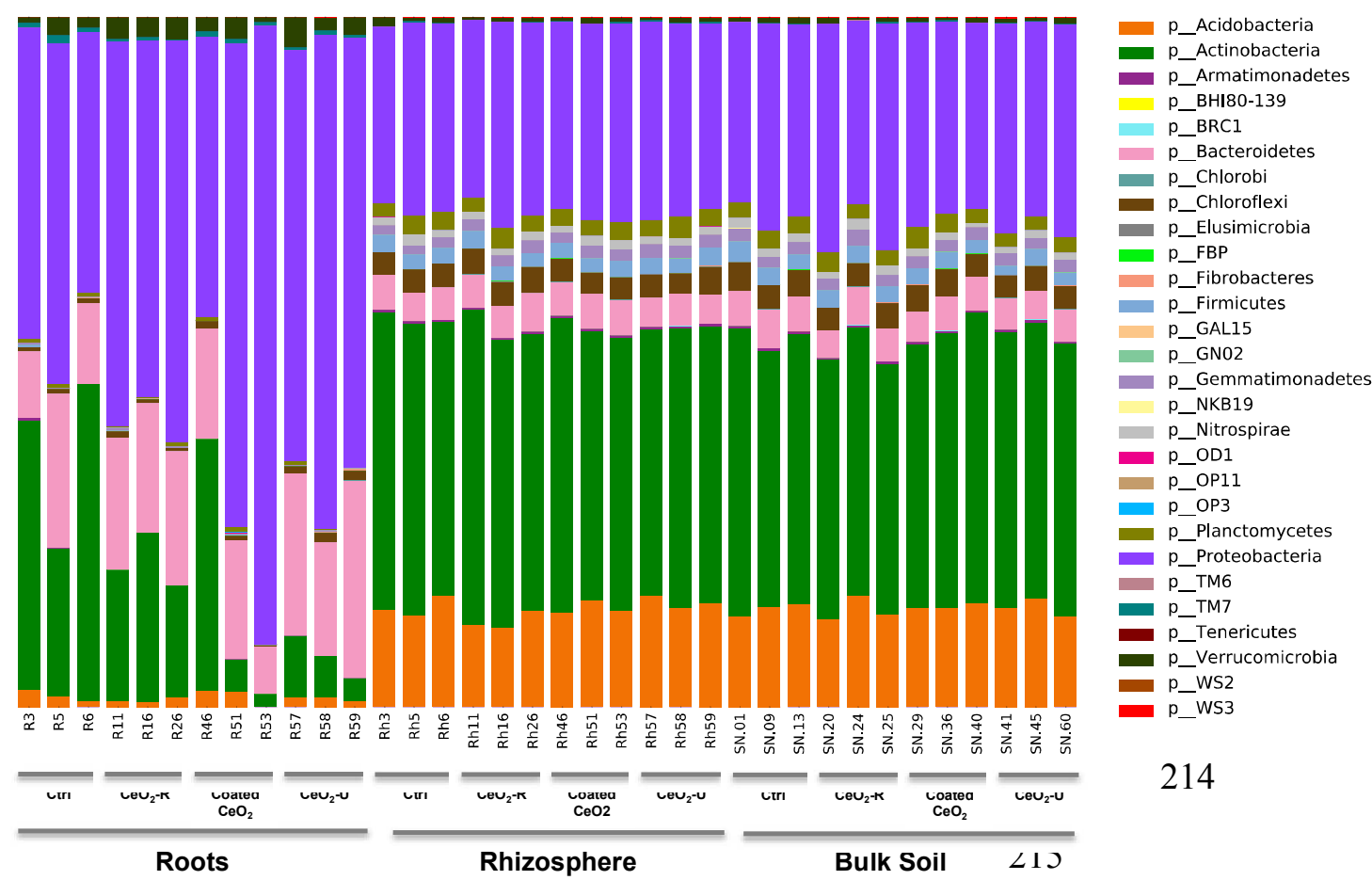

218 Figure S4: Percent composition of each group by phylum in root, rhizosphere and bulk soil

219 compartments for plants grown in soil enhanced with nanoceria (pristine $\mathrm{CeO}_{2}-\mathrm{R}, \mathrm{CeO}_{2}-\mathrm{U}$ and citrate 220 coated $\mathrm{CeO}_{2}$ ) at $1 \mathrm{mg} \cdot \mathrm{kg}^{-1}$ or with no nanoceria (controls, Ctrl). 


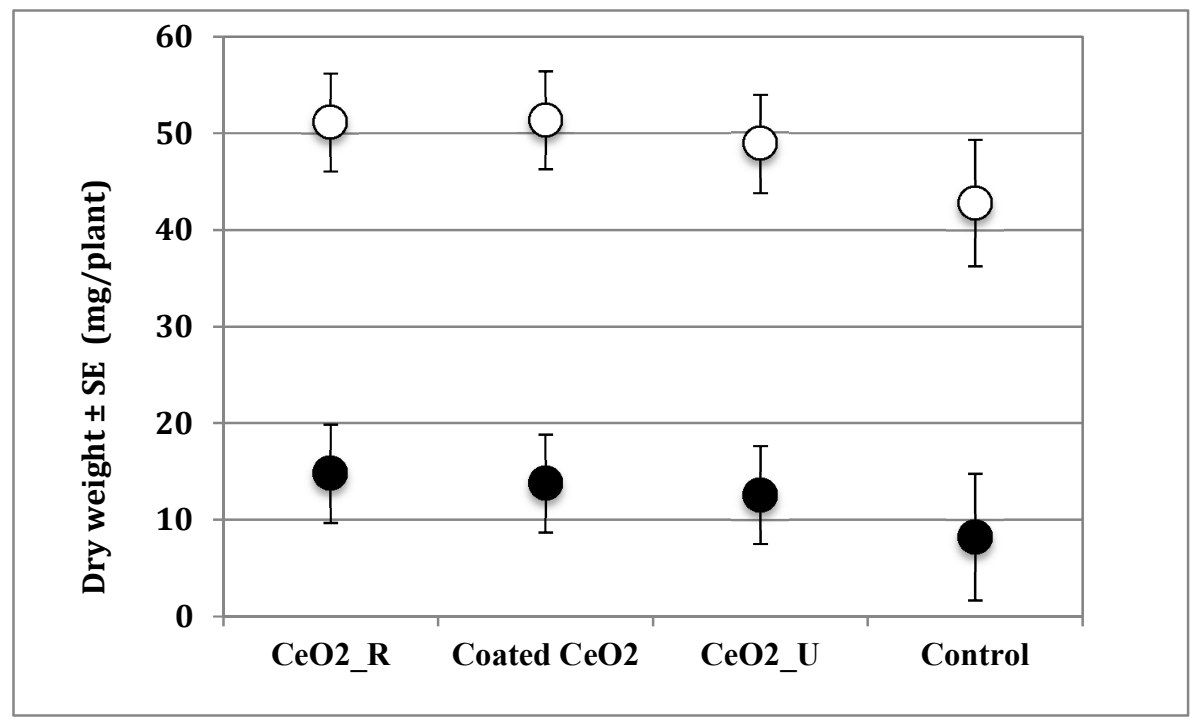

241

242

243 Figure S5: Impact of nanoceria on plant growth. Dry mass ( \pm standard error, SE) of plant shoots 244 (white circles) and roots (dark circles) for plants grown for $30 \mathrm{~d}$ in a clay-loam calcareous soil (pH 245 8.19) enhanced with $1 \mathrm{mg} \cdot \mathrm{kg}^{-1}$ of nanoceria and for controls. ANOVA analysis showed no significant 246 effect of nanoceria $(\mathrm{P} \geq 0.05)$.

247 
248 Table S1: Physico-chemical characteristics of nanoceria in ultrapure water (1 mg. $\left.\mathrm{L}^{-1}\right)$.

\begin{tabular}{ccccccc}
\hline $\mathrm{NM}$ & $\begin{array}{c}\text { Average } \\
\text { diameter }(\mathrm{nm}) \\
\text { DLS* }\end{array}$ & $\begin{array}{c}\text { Average particle } \\
\text { size }(\mathrm{nm}) \\
\text { TEM** }\end{array}$ & $\begin{array}{c}\text { Zeta potential } \\
(\mathrm{mV})\end{array}$ & $\begin{array}{c}\text { Isoelectric } \\
\text { point }\end{array}$ & $\begin{array}{c}\text { Specific } \\
\text { surface area } \\
\mathrm{m}^{2} . \mathrm{g}^{-1}\end{array}$ & Reference \\
\hline \hline $\mathrm{CeO}_{2}-\mathrm{R}$ & 8 & $3-4$ & $26.4(\mathrm{pH} \mathrm{5)}$ & $7.0-7.5$ & $\mathrm{ND}$ & $\begin{array}{c}\text { Barton et } \\
\text { al., 2014 }\end{array}$ \\
$\mathrm{CeO}_{2}-\mathrm{U}$ & 170 & $31 \pm 18$ & $15(\mathrm{pH} \mathrm{5)}$ & $7.8 \pm 2$ & $56 \pm 10$ & $\begin{array}{c}\text { Tella et al., } \\
2015\end{array}$ \\
$\begin{array}{c}\mathrm{Coated}- \\
\mathrm{CeO}_{2}\end{array}$ & 8 & $3.9 \pm 1.8$ & $-40(\mathrm{pH} 3$ to 10) & & $271 \pm 177$ & $\begin{array}{c}\text { Tella et al., } \\
2015\end{array}$ \\
\hline
\end{tabular}

249

250 *DLS: Dynamic light scattering

251 **TEM: Transmission electron microscopy

252 
253 Table S2: Characteristics of soil used in the study.

254

\begin{tabular}{llr}
\hline Element & Unit & \\
\hline \hline $\mathrm{MO}$ & $\mathrm{g} / \mathrm{kg}$ & 43.8 \\
$\mathrm{C}$ & $\mathrm{g} / \mathrm{Kg}$ & 25.4 \\
$\mathrm{~N}$ & $\mathrm{~g} / \mathrm{kg}$ & 2.43 \\
$\mathrm{P}$ & $\mathrm{g} / \mathrm{kg}$ & 0.036 \\
$\mathrm{P}$ assimilable (Olsen) & $\mathrm{g} / \mathrm{kg}$ & 0.016 \\
$\mathrm{~K}_{2} \mathrm{O}$ & $\mathrm{g} / \mathrm{kg}$ & 0.125 \\
$\mathrm{MgO}$ & $\mathrm{g} / \mathrm{kg}$ & 0.179 \\
$\mathrm{~K} / \mathrm{Mg}$ ratio & & 0.7 \\
$\mathrm{CaO}$ & $\mathrm{g} / \mathrm{kg}$ & 12.99 \\
$\mathrm{~B}$ & $\mathrm{mg} / \mathrm{kg}$ & 0.18 \\
$\mathrm{Cu}$ & $\mathrm{mg} / \mathrm{kg}$ & 4.1 \\
$\mathrm{Zn}$ & $\mathrm{mg} / \mathrm{kg}$ & 3.5 \\
$\mathrm{Mn}$ & $\mathrm{mg} / \mathrm{kg}$ & 19.4 \\
$\mathrm{Fe}$ & $\mathrm{mg} / \mathrm{kg}$ & 8.2 \\
$\mathrm{Ce} *$ & $\mathrm{mg} / \mathrm{kg}$ & 19 \\
$\mathrm{pH}$ (water) & & 8.19 \\
\hline
\end{tabular}

255

256 *: Ce content was determined after mineralization of soil in $\mathrm{HNO}_{3}(75 \%$ analytical grade), using an

257 inductively coupled plasma atomic emission spectrometry (ICP-AES Varian).

258

259

260 
261 Table S3: Extractable soil DNA and bacterial abundance in the different treatments. R is the relative

262 quantification of the rss gene based on the expression levels in a treatment versus control.

263

\begin{tabular}{|c|c|c|c|c|c|c|c|}
\hline Compartment & Treatment & $\begin{array}{l}\text { DNA extracted } \\
\left(\mathrm{ng} \mathrm{g}^{-1}\right)\end{array}$ & $\begin{array}{c}\text { Mean DNA } \\
\text { extracted } \\
\left(\mathrm{ng} \mathrm{g}^{-1}\right)\end{array}$ & SD & $\mathbf{R}$ & $\begin{array}{c}\text { R } \\
\text { (mean of } 3 \\
\text { replicates) }\end{array}$ & SD \\
\hline \multirow{12}{*}{ Bulk soil } & Control & 354 & 340 & 15 & 1.2 & 1.0 & 0.2 \\
\hline & Control & 325 & & & 0.9 & & \\
\hline & Control & 341 & & & 1.0 & & \\
\hline & $\mathrm{CeO}_{2}-\mathrm{R}$ & 370 & 368 & 51 & 0.9 & 1.0 & 0.1 \\
\hline & $\mathrm{CeO}_{2}-\mathrm{R}$ & 316 & & & 1.2 & & \\
\hline & $\mathrm{CeO}_{2}-\mathrm{R}$ & 417 & & & 1.0 & & \\
\hline & Coated $\mathrm{CeO}_{2}$ & 345 & 348 & 5 & 1.0 & 1.2 & 0.5 \\
\hline & Coated $\mathrm{CeO}_{2}$ & 354 & & & 0.8 & & \\
\hline & Coated $\mathrm{CeO}_{2}$ & 345 & & & 1.8 & & \\
\hline & $\mathrm{CeO}_{2}-\mathrm{U}$ & 339 & 348 & 23 & 1.3 & 1.5 & 0.3 \\
\hline & $\mathrm{CeO}_{2}-\mathrm{U}$ & 332 & & & 1.5 & & \\
\hline & $\mathrm{CeO}_{2}-\mathrm{U}$ & 374 & & & 1.9 & & \\
\hline \multirow{12}{*}{ Rhizosphere } & Control & 311 & 322 & 11 & 1.0 & 1.0 & 0.2 \\
\hline & Control & 333 & & & 1.2 & & \\
\hline & Control & 321 & & & 0.8 & & \\
\hline & $\mathrm{CeO}_{2}-\mathrm{R}$ & 367 & 358 & 8 & 1.2 & 1.1 & 0.2 \\
\hline & $\mathrm{CeO}_{2}-\mathrm{R}$ & 354 & & & 1.3 & & \\
\hline & $\mathrm{CeO}_{2}-\mathrm{R}$ & 354 & & & 0.9 & & \\
\hline & Coated $\mathrm{CeO}_{2}$ & 358 & 312 & 42 & 1.1 & 1.0 & 0.2 \\
\hline & Coated $\mathrm{CeO}_{2}$ & 275 & & & 0.8 & & \\
\hline & Coated $\mathrm{CeO}_{2}$ & 303 & & & 1.2 & & \\
\hline & $\mathrm{CeO}_{2}-\mathrm{U}$ & 324 & 345 & 21 & 1.1 & 1.1 & 0.1 \\
\hline & $\mathrm{CeO}_{2}-\mathrm{U}$ & 366 & & & 1.1 & & \\
\hline & $\mathrm{CeO}_{2}-\mathrm{U}$ & 345 & & & 1.0 & & \\
\hline
\end{tabular}


270 Table S4: Statistical significance between treatments at the phylum taxonomic level in the root

271 compartment based on UniFrac-based distance matrices and PERMANOVA (999 Monte Carlo

272 permutations). Significance was defined as $\mathrm{P}<0.05$.

273

274

\begin{tabular}{|c|c|c|c|}
\hline Compartment & Treatment & $\begin{array}{c}\text { Unweight } \\
\text { ed } \\
\text { UniFrac } \\
\text { distance }\end{array}$ & $\begin{array}{l}\text { Weighted } \\
\text { UniFrac } \\
\text { distance }\end{array}$ \\
\hline Root & Coated $\mathrm{CeO}_{2}$ vs. $\mathrm{CeO}_{2}-\mathrm{U}$ & 0.022 & NS \\
\hline Root & Control vs. $\mathrm{CeO}_{2}-\mathrm{U}$ & 0.042 & 0.002 \\
\hline Root & $\mathrm{CeO}_{2}-\mathrm{R}$ vs. $\mathrm{CeO}_{2}-\mathrm{U}$ & NS & 0.005 \\
\hline Rhizosphere & Coated $\mathrm{CeO}_{2}$ vs. $\mathrm{CeO}_{2}-\mathrm{R}$ & 0.026 & NS \\
\hline Rhizosphere & $\mathrm{CeO}_{2}-\mathrm{R}$ vs. $\mathrm{CeO}_{2}-\mathrm{U}$ & 0.035 & NS \\
\hline
\end{tabular}

275 NS: Non significant

276

277 
278 Table S5: Significant differences in relative abundances between treatments at phylum taxonomic

279 level in the root compartment. $\mathrm{P} \leq 0.05$; FDR Q-value $<0.25$.

280

\begin{tabular}{llcccc}
\hline Treatments & Phylum level & \multicolumn{2}{c}{$\begin{array}{c}\text { Kruskal-Wallis } \\
\text { analysis }\end{array}$} & Abundance (\%) \\
& \multicolumn{4}{c}{} \\
\hline \hline $\begin{array}{l}\mathbf{C e O}_{2} \text {-U } \\
\text { vs. Ctrl }\end{array}$ & Taxon & P-value & $\begin{array}{c}\text { FDR } \\
\text { Q-value }\end{array}$ & Control & $\mathbf{C e O}_{2}$-U \\
& Fibrobacteres & 0.0181 & 0.0651 & 0.02 & 0.16 \\
& Actinobacteria & 0.0186 & 0.0651 & 37.4 & 6.3 \\
& Chloroflexi & 0.0186 & 0.0651 & 0.66 & 1.2 \\
& Proteobacteria & 0.0186 & 0.0651 & 42.8 & 64.1
\end{tabular}

$\begin{array}{llcrcc}\begin{array}{l}\mathbf{C e O}_{2}-\mathbf{R} \\ \text { vs. Ctrl }\end{array} & \text { Taxon } & \text { P-Value } & \begin{array}{c}\text { FDR } \\ \text { Q-value }\end{array} & \text { Control } & \mathbf{C e O}_{2}-\mathbf{R} \\ & \text { Armatimonadetes } & 0.0463 & 0.1734 & 0.16 & 0.01 \\ & \text { Proteobacteria } & 0.0495 & 0.1734 & 42.7 & 54.6 \\ & \text { TM7 } & 0.0495 & 0.1734 & 0.75 & 0.32 \\ & \text { Verrucomicrobia } & 0.0495 & 0.1734 & 1.6 & 3.0\end{array}$

$\begin{array}{llrrrc}\begin{array}{l}\mathbf{C e O}_{2}-\mathbf{U} \\ \text { vs. } \mathbf{C e O}_{2}-\mathbf{R}\end{array} & \text { Taxon } & \text { P-Value } & \begin{array}{c}\text { FDR } \\ \text { Q-value }\end{array} & \mathbf{C e O}_{2}-\mathbf{R} & \mathbf{C e O}_{2}-\mathbf{U} \\ & \text { Actinobacteria } & 0.0495 & 0.2311 & 21.0 & 6.3 \\ & \text { Chloroflexi } & 0.0495 & 0.2311 & 0.63 & 1.2 \\ & \text { Proteobacteria } & 0.0495 & 0.2311 & 54.6 & 64.1\end{array}$


Table S6: Analysis of differences in relative abundance at the family, genus and species levels. OTU counts of abundant community members $(>0.1 \%)$ rarefied to 1,067 OTUs were analyzed by ANOVA. Significance was defined as $\mathrm{P}<0.05$ and FDR Q-value $<0.25$

\begin{tabular}{|c|c|c|c|c|c|}
\hline Treatment & taxonomy & P-value & Q-value & $\begin{array}{c}\text { Root Control } \\
\text { abundance } \\
(\%)\end{array}$ & $\begin{array}{c}\mathrm{Root} \mathrm{CeO}_{2}-\mathrm{U} \\
\text { abundance } \\
(\%)\end{array}$ \\
\hline \multirow{12}{*}{$\begin{array}{c}\mathrm{CeO}_{2}-\mathrm{U} \text { vs. } \\
\text { Control }\end{array}$} & Proteobacteria;c_Betaproteobacteria;o__Burkholderiales;f_Comamonadaceae; $g$ _Acidovorax & 0.0004 & 0.016 & 0.22 & 5.65 \\
\hline & Actinobacteria;c_Actinobacteria;o__Actinomycetales; _Streptomycetaceae;g_Streptomyces;s_ & 0.0005 & 0.016 & 6.06 & 0.69 \\
\hline & Proteobacteria;c_Betaproteobacteria;o_Burkholderiales; $f$ Comamonadaceae $; g \_$Methylibium;s_ & 0.0043 & 0.078 & 4.94 & 21.90 \\
\hline & Proteobacteria;c_Betaproteobacteria;o_Burkholderiales; $f$ Comamonadaceae & 0.0048 & 0.078 & 0.59 & 2.75 \\
\hline & Proteobacteria;c_Gammaproteobacteria;o_Xanthomonadales; $f$ Xanthomonadaceae;g_Pseudoxanthomonas & 0.0116 & 0.151 & 4.62 & 0.62 \\
\hline & Actinobacteria;c_Actinobacteria;o_Actinomycetales;f_Actinosynnemataceae & 0.0211 & 0.204 & 6.69 & 0.25 \\
\hline & Proteobacteria;c_Betaproteobacteria;o_Burkholderiales; $f$ _Oxalobacteraceae $; g$ Janthinobacterium;s & 0.0250 & 0.204 & 12.46 & 3.03 \\
\hline & Actinobacteria;c_Actinobacteria;o_Actinomycetales; $f$ Nocardioidaceae;g_Kribbella;s_ & 0.0252 & 0.204 & 1.97 & 0.28 \\
\hline & Proteobacteria;c_Betaproteobacteria;o_Burkholderiales; $f$ _Comamonadaceae $; g \_$Pelomonas;s_ & 0.0283 & 0.204 & 1.69 & 7.65 \\
\hline & Actinobacteria;c_Actinobacteria;o_Actinomycetales;__Actinosynnemataceae & 0.0385 & 0.217 & 3.84 & 0.12 \\
\hline & Actinobacteria;c_Actinobacteria;o_Actinomycetales; $f$ _Micrococcaceae;g_; & 0.0390 & 0.217 & 0.25 & 0.00 \\
\hline & Proteobacteria;c_Betaproteobacteria;o__Burkholderiales;f_Comamonadaceae;g_Methylibium;s_ & 0.0401 & 0.217 & 2.66 & 16.43 \\
\hline Treatment & taxonomy & P-value & Q-value & $\begin{array}{c}\mathrm{Root}_{\mathrm{CeO}}-\mathrm{R} \\
\text { abundance } \\
(\%)\end{array}$ & $\begin{array}{c}\mathrm{Root}_{\mathrm{CeO}}-\mathrm{U} \\
\text { abundance } \\
(\%)\end{array}$ \\
\hline \multirow{9}{*}{$\begin{array}{c}\mathrm{CeO}_{2}-\mathrm{U} \text { vs. } \\
\mathrm{CeO}_{2}-\mathrm{R}\end{array}$} & Actinobacteria;c_Actinobacteria;o_Actinomycetales;f_Micrococcaceae;g_; __ & 0.0022 & 0.051 & 0.22 & 0.00 \\
\hline & Proteobacteria;c_Betaproteobacteria;o_Burkholderiales;f_Oxalobacteraceae;g_Janthinobacterium;s_ & 0.0026 & 0.051 & 17.74 & 3.03 \\
\hline & Proteobacteria;c_Betaproteobacteria;o_Burkholderiales;__Comamonadaceae;g_Methylibium;s_ & 0.0028 & 0.051 & 7.28 & 21.90 \\
\hline & Proteobacteria;c_Betaproteobacteria;o_Burkholderiales; $f$ _Comamonadaceae; $g$ _Acidovorax & 0.0050 & 0.067 & 1.31 & 5.65 \\
\hline & Actinobacteria;c_Actinobacteria;o_Actinomycetales; $f$ Actinosynnemataceae & 0.0084 & 0.091 & 6.00 & 0.25 \\
\hline & Actinobacteria;c_Actinobacteria;o_Actinomycetales;f_Streptomycetaceae & 0.0297 & 0.245 & 10.03 & 0.59 \\
\hline & Proteobacteria;c_Betaproteobacteria;o_Burkholderiales;f_Comamonadaceae;g_Methylibium;s_ & 0.0393 & 0.245 & 2.72 & 16.43 \\
\hline & Proteobacteria;c_Betaproteobacteria;o_Burkholderiales; f_Comamonadaceae & 0.0403 & 0.245 & 0.94 & 2.75 \\
\hline & Proteobacteria;c_Betaproteobacteria;o_Burkholderiales;f_Comamonadaceae; __Variovorax;s_paradoxus & 0.0408 & 0.245 & 5.25 & 1.69 \\
\hline
\end{tabular}

\section{References}

1. Li, F.; Yu, J.; Nong, M.; Kang, S.; Zhang, J., Partial root-zone irrigation enhanced soil enzyme activities and water use of maize under different ratios of inorganic to organic nitrogen fertilizers. Agr. Water Manage. 2010, $97 \quad$ (2), 231-239; DOI 10.1016/j.agwat.2009.09.014

2. Turner, B. L.; Hopkins, D. W.; Haygarth, P. M.; Ostle, N., ß-Glucosidase activity in pasture soils. Appl. Soil Ecol. 2002, 20 (2), 157-162; DOI: 10.1016/S0929-1393(02)00020-3.

3. Saiya-Cork, K. R.; Sinsabaugh, R. L.; Zak, D. R., The effects of long term nitrogen deposition on extracellular enzyme activity in an Acer saccharum forest soil. Soil Biol. Biochem. 2002, 34 (9), 1309-1315; DOI 0.1016/S0038-0717(02)00074-3. 
4. Ge, Y.; Schimel, J. P.; Holden, P. A., Identification of Soil Bacteria Susceptible to $\mathrm{TiO} 2$ and $\mathrm{ZnO}$ Nanoparticles. Appl. Environ. Microbiol. 2012, 78 (18), 6749-6758; DOI 10.1128/AEM.00941-12.

5. Anupama, V. N.; Amrutha, P. N.; Chitra, G. S.; Krishnakumar, B., Phosphatase activity in anaerobic bioreactors for wastewater treatment. Water Res. 2008, 42 (10-11), 27962802; DOI 10.1016/j.watres.2008.02.014.

6. Bargaz, A.; Faghire, M.; Abdi, N.; Farissi, M.; Sifi, B.; Drevon, J.-J.; Cherkaoui Ikbal, M.; Ghoulam, C., Low Soil Phosphorus Availability Increases Acid Phosphatases Activities and Affects P Partitioning in Nodules, Seeds and Rhizosphere of Phaseolus vulgaris. Agriculture 2012, 2 (2), 139-153; DOI 10.3390/agriculture2020139.

7. Muyzer, G.; De Waal, E. C.; Uitterlinden, A. G., Profiling of complex microbial populations by denaturing gradient gel electrophoresis analysis of polymerase chain reactionamplified genes coding for 16S rRNA. Appl. Environ. Microbiol. 1993, 59 (3), 695-700.

8. Dowd, S. E.; Callaway, T. R.; Wolcott, R. D.; Sun, Y.; McKeehan, T.; Hagevoort, R. G.; Edrington, T. S., Evaluation of the bacterial diversity in the feces of cattle using $16 \mathrm{~S}$ rDNA bacterial tag-encoded FLX amplicon pyrosequencing (bTEFAP). BMC Microbiol. 2008, 8 (1), 125; DOI 10.1186/1471-2180-8-125.

9. Caporaso, J. G.; Kuczynski, J.; Stombaugh, J.; Bittinger, K.; Bushman, F. D.; Costello, E. K.; Fierer, N.; Pe $\sqrt{ } \pm$ a, A. G.; Goodrich, J. K.; Gordon, J. I.; Huttley, G. A.; Kelley, S. T.; Knights, D.; Koenig, J. E.; Ley, R. E.; Lozupone, C. A.; McDonald, D.; Muegge, B. D.; Pirrung, M.; Reeder, J.; Sevinsky, J. R.; Turnbaugh, P. J.; Walters, W. A.; Widmann, J.; Yatsunenko, T.; Zaneveld, J.; Knight, R., QIIME allows analysis of high-throughput community sequencing data. Nat. Methods 2010, 7, (5), 335-336; DOI 10.1038/nmeth.f.303. 
10. Lozupone, C.; Lladser, M. E.; Knights, D.; Stombaugh, J.; Knight, R., UniFrac: an effective distance metric for microbial community comparison. ISME J. 2011, 5, (2), 169; DOI 10.1038/ismej.2010.133. 